\title{
THE HUMANITIES AND NATIONAL IDENTITY, SECURITY AND SOCIAL STABILITY IN NIGERIA: HISTORY AND THEATRE AS THE WAY FORWARD
}

\author{
Ama Doki Gowon \\ Benue State University, Makurdi, Nigeria \\ \& \\ Elijah Terdoo Ikpanor \\ Benue State University, Makurdi, Nigeria \\ *http://dx.doi.org/10.4314/ujah.v14i3.1
}

\section{Abstract}

The humanities give a real sense of understanding and interpretation to the social, cultural, economic as well as the interpersonal relationships in societies both at the level of individuals and institutions. Because human beings are dynamic and complex in nature, their perceptive actions must be examined under a foundation that gives meaning to diverse composition of expressions and manifestations of those challenges that affect them. The humanities' responsibility is to negotiate the challenges and prospects of societies with a view to evolving pragmatic ways of appropriating nature. Thus, knowledge gained from studies in the humanities has the potentials of instituting and championing cultural assimilation which ultimately, translates to national identity and or consciousness de-emphasizing in the process ethnicity in favour of social stability as a pre-requisite for security. This paper has examined the role of the humanities in creating national identity among Nigerians. In so-doing, the paper has looked at clarification of concepts like the humanities, national identity ethnicity and security. The paper also looks at the possibility of the humanities in providing a solution to the challenges of Nigeria in terms of national identity and security. The paper thus is of the opinion that more attention and researches needs to be carried out in the humanities if Nigeria is to tackle the current security challenges of the nation. 
The Humanities and National Identity, Security and Social Stability in Nigeria: History and Theatre as the way Forward- Ama Doki Gowon, PhD, \& Elijah Terdoo Ikpanor

\section{Introduction}

The challenge of Nigeria ranging from ethnic tensions to insecurity has threatened the unity of the country and calls for genuine solutions for the survival of the country as a nation. Ethnic identity and consciousness create inter-ethnic rivalry among different ethnic groups in Nigeria and also pose a challenge to the quest for national identity. The humanities in terms of academic disciplines that study humanity through culture, experience and activities of human beings have over a long period of time given fundamental sense of reality to the evolution and existence of national identity in Nigeria. The humanities in various ways have provided a platform for the understanding of the complexities in national integration especially in analyzing human behaviour in relation to response to the challenges of existence. National cohesion that opposes ethnic consciousness is understood through social, cultural, historical and ethical roles of humanities in advancing unity through common experience in Nigeria. This paper therefore explores the relevance of the humanities in fostering National Identity in Nigeria and the corresponding impact of the problem of ethnicity, security and social stability in Nigeria. This discourse will therefore begin with conceptual clarification to put the discussion in clear focus.

\section{Conceptual Clarification}

Key concepts elucidated in this discourse include the Humanities, National Identity, Ethnicity, Security and Political Stability. The explanation of these concepts is genuine because they focus on the activities of human beings in the society. Thus, Humanities have attracted wide scholarly patronage in explanation. Nevertheless, all explanations see the humanities 
as an umbrella under which human beings have been able to use philosophy, literature, religion, art, music, history and language to record and understand the world. Largely, the humanities encompass the study of numerous approaches in which people used every period of time and every part of the world to understand and document the human experience. It is the knowledge of documentations of human activities that provides humanity the opportunity to connect with past generations and explain complexities of existence and challenges of human development either in economy, politics, social, religious or cultural challenges. Adam Roberts gives an insight into the ideas of the humanities. According to him; the humanities explore what it means to be human; the words, ideas, narratives and the art and artifacts that help us make sense of our lives and the world we live in; how we have created it, and are created by it (2010:2). It is in line with this milieu that Renz, Steven and Smith identified particular areas that explore these human ideals. They identified these in line with the United State's National Endowment for the Humanities which says the "humanities include; but is not limited to, the study of language; both modern and classical, linguistics, literature, history, jurisprudence, philosophy, archeology, comparative religion, ethics..., those aspects of social sciences which have humanistic content and employ humanistic methods; the study and application of the humanities to the human environment with particular attention to reflecting our diverse heritage, traditions and history and to the relevance of the humanities to the current conditions of national life (2004:2). The humanities serve the critical role of developing and preserving human thought and culture in the society. 
Societies on the other hand respond to determinants in environment that advance interrelationship of human beings. The study of patterns of human culture and their relationship in different human societies create opportunities in understanding common identities for collective survival or sustained existence. The humanities therefore encourage the study and understanding of human activities or culture and their connection with different conditions is cogged on past experiences and interpretation of human existence.

National Identity on the other hand, involves the manifestation of absolute sameness at a macro level involving different members of different backgrounds. Thus, National Identity is that which relates to people of the same nation, showing the quality of being of the same kind and having a sense of absolute sameness and identifying with the aims and objectives of the nation. In this situation, it is obvious that ethnic consciousness is deemphasized and national consciousness promoted among diverse cultures. This situation fosters unity that is requisite for peaceful co-existence, cohesion and social stability. However, national identity translates to national integration which Aliyu (1975) argues to be the achievement of a cohesive society in which different cultural and social aggregates come together into a strong pre-eminent sense of national identity and the process of establishing a minimum value consensus for the purpose of maintaining a stable social order. National identity in this discourse denotes the expression or process of categorization of groups from different backgrounds under different culture (ethnic, religious, gender, etc) into common shared or presumed platform of collectivity.

Ethnicity on the other has diverse explanations from different scholars. According to Omu (1999:3) the concept of ethnicity 
applies to the consciousness of belonging to, identifying with and being loyal to a social group distinguished by share cultural traditions, a common language, in-group sentiment and self identity. This is the manifestation of group identity characterized by language, shared historical origin, cultural and religious experiences. Ethnic consciousness under this guise promotes prejudices and supports sentiments of inclusion, therefore, promoting a stereotypical relationship with the excluded groups outside the members of an ethnic group.

Security as observed by Imobighe is very difficult to conceptualize even though there is much interest in issues that concerns it with peace. The ambiguity in the concept of security is because of its multi-dimensional components both in the internal (local) and external (international) environment. Thus, Imobighe (1992:34) sees security as "freedom from danger or with threats to a nation's ability to protect itself, promote its cherished values and legitimate interests and enhance the well-being of its people. Security on the other hand, can be understood in the context of the condition that enhances the ability of government, its agencies and its citizens to operate without hindrances. Section 14 (1) of chapter of the (1999) constitution of the federal republic of Nigeria explains the significance of security when it maintains that security and welfare of the people shall be the primary purpose of government. It emphasizes that, "security is a social contract between the state and its citizens, in which the former is expected to protect, defend and provide for the latter in the public area." Expansively, National security in its wide sense connotes the lack of threat to life, property and socio-economic well being of the people. The developmental connotation of national security is corroborated by khan (1987:54). To him, 
national security is taken to mean the totality of measures instituted by government to protect the territorial integrity and the cherished values, and interest of the people as well as guarantee the freedom of the citizenry from anxiety, threats to life and property and their safety from natural or manmade disasters. On this end, Ogunbanwo (1997) listed types of security to include economic security, social security, environmental security, food security, the quality of life security and technological security. Finally Imobighe (2002) in conceptualizing security observed that the process of development involves the application of national resources, human, mineral and agricultural for the enrichment of the live of the population. It is the enrichment that constitutes development. It does not only presuppose the growth in income (economic growth), but also requires improvement in certain indicators health, nutrition, education reduction in certain inequalities income distribution.

There is much about internal security as conceived in the conception of Imobighe who stressed that it involves freedom and safety of life and property of people in a better environment as members of a society. Security necessarily seeks peaceful environment as an end result. Peace therefore, ensures harmonious relationship and absence of violence in the society. This discourse is guided by the understanding of peace as a situation where there is absence hostility but state of harmony between individuals and groups. As its main trust, this discourse sees Nigeria as a nation with multi-ethnic identities that pursue peace on the foundation of diverse identities which rather threatens the security situation of the country. 


\section{Understanding National Identity, Ethnicity, Security: The Nigerian Situation}

National identity in Nigeria is addressed with its accompanying challenges by different scholars. Ikime (2002:67) and Ibrahim (2003:120) see colonialism as the factor for the challenge of National Identity in Nigeria. To them, colonialism has through the imposition of indirect rule, brought discrete and smaller tribes under the rulership of the dominant ones and thus, created problems of identity and a sense of belonging. The various identities and cultures of these ethnic groups become apparent from this reaction against domination. As argued by Ibrahim (2000:41), ethnic-regional conflicts tend to emerge at moments when groups perceive that they are being excluded from access to what they consider to be their right, be they linguistic, political, economic, administrative, commercial, religious etc. Each ethnic group in Nigeria because of the postulation of Ibrahim, feels dissatisfied and struggle for an identity of its own. The subjugation of the minor ethnic groups in 1914 amalgamation now became a challenge in managing the politics of inclusion in access to land, public appointments and the control of valued resources and wealth. These excluded ethnic groups subsumed under regions immediately after Nigeria's independence and began to agitate for their own identity. These agitations were linked with political representation as well as access to and control of resources. These struggles especially in the Niger Delta communities often take on the materialist interpretation in terms of control over oil revenue. Other identity and self determination struggles are over land. All these obviously affect the national identity of Nigeria with further complications in the practice where minorities at the centre (federal level) are sometimes majority at the regional (state and local) levels. Thus, similar struggles at the centre over fear of 
The Humanities and National Identity, Security and Social Stability in Nigeria: History and Theatre as the way Forward- Ama Doki Gowon, PhD, \& Elijah Terdoo Ikpanor

domination and denial of self-determination of the centre are replicates of regional and local identities; a situation that threatens social stability in Nigeria.

More so, Nigeria is bedeviled with enormous challenges of ethnicity, security that are threats to social stability and national identity since the return to democracy in May 1999. The period between 1999 and 2013 provided Good Avenue for more challenge of national identity because of the manifestation of ethnic contestations and consciousness in the control of the machinery of government. This scenario has brought a high spate of ethnic violence and disturbances through different patterns of exclusive and domination of few major ethnic groups over large minor groups who have consolidated their grip on state institutions to the exclusion of others (Mustapha, 1997:27-28). The manifestation of ethnic identity instead of national identity is articulated in all aspects of democratic practice in Nigeria beginning from elections to appointments and location of projects where some ethnic groups are placed on the advantage against others.

Obviously, various ethnic groups that constitute Nigeria often than not group and regroup under regional or ethnic platforms and invisibly pose a threat to the social stability of the country because any favour to a group of any platform attracts large resistance from others. Looking at the violent dimensions of challenges of national security, Mohammed Kuna (1997:71) observed that issues of violence were resurfacing with terrible consequences where conflicts religious, communal and ethnic have been on the increase with a challenge to social stability. The central argument in some of these conflicts is allegations of state support or favour to further the cause of some ethnic groups. The frequent outbreak of ethnic violence is a function of the fear of domination where the security of one ethnic 
group is the destruction of the other. Thus, fears in ethnic interactions has even produced at different periods paramilitary units such as the O'dua people's congress which is the Youth wing of Afenifere, the Bakasi boys in the Eastern States and Egbesu boys in the Niger Delta. These militia groups are not too unconnected with ethnic conscious groups like Afenifere campaign of the Yoruba nation, the Arewa People's congress and Arewa Consultative Forum for the old north, the Ohanze of Ibos, the Niger Delta Forum and the Middle Belt Forum. These identities marked ethnicity, religion and region based definition of Nigeria before the amalgamation of 1914. The persistence of these centrifugal forces has continued to challenge the national security of Nigeria. The phenomenon of militias accompanying ethnic identities has sometimes precipitated inter-ethnic violence and the state of social instability. They are often used in open violence during elections where contending political candidates employ their services to advance their quest for political control. Generally, ethnic competitions in Nigeria are patent with the struggle for more participation in national affairs, economic prospects and the country of resources.

\section{The Role of the Humanities in Nigeria's National Identity and Security}

Intellectual impulses and scholarly quest in the humanities strengthens the national identity that will de-emphasize ethnicity and provide national security for the teaming population of the country. The challenges of security on the other hand are inextricably connected with the country's history, culture, social structure and economic conditions. However, the humanities in more specific terms, illuminates perspectives on ethnic cultural development and the dynamics that have altered Nigerian security especially in the areas of 
The Humanities and National Identity, Security and Social Stability in Nigeria: History and Theatre as the way Forward- Ama Doki Gowon, PhD, \& Elijah Terdoo Ikpanor

crises such as, terrorism, intra and inter-ethnic conflicts, religious intolerance, kidnapping, political violence, armed robbery and secret-cult activities etc that have threatened social stability of Nigeria. All these security challenges can be addressed through the ethos of humanities responses to Nigeria's national identity and development.

A proper understanding of security through the humanities is important for an adequate explanation of the remote causes of breach of peace and security, whether historical, religious, civil, ethnic, economic, social, political etc, that have contributed to the recurring conflicts, which the nation has witnessed over the years resulting in wanton destruction and loss of live and property. Security has implication for individuals, communities and the nation and must be analyzed at these various levels. Certain factors which can be explained by the humanities knowledge tend to increase the vulnerability of people to insecurity. These include gender, class, age, status, ethnicity, religion, ecology, region etc. This is because as argued by Arisi, Regina (2011: 258) it is important that contemporary thinking about national security has be more encompassing involving social, political, economic and other forms of the security calculation, culminating in the concern for human security and improvement in the quality of the people. The humanities knowledge provides the understanding of unprecedented level of insecurity in Nigeria especially intercommunal and inter-ethnic clashes, religious violence, armed robbery, assassination, murder, gender-based violence and bomb explosion which have been on the increase leading to enormous loss of life and property and a general atmosphere of siege and social tension from the people. The humanities emphasizes that the state exists primarily for the protection of lives and property and ensuring the well being of the people. 
Through language, the people of Nigeria have understood the cultural similarities that fused them together before the arrival of Europeans. The adoption of English language as a lingua franca and its study has facilitated multi-cultural knowledge among the people of Nigeria. The humanities promote reflection and research on histories, languages and cultures of inter-group relations that have lasted for centuries before the contact the people of Nigeria with the Europeans. It also provides the understanding of history and culture of Nigeria where colonial government was able to create common identities by the creation of a standard language and the deployment of common myths of origin. Languages that were hardly mutually comprehensible became fixed on the basis of common language. Thus, literally documents also reflect history, cultural, economic, religion and politics of the people. The creation of historical novels provides unique knowledge of the people's culture. Thus, the humanities through language have also informed the Nigerian people of the identity either through written or oral expression. This understanding of each other through communication aids the people from different ethnic backgrounds to comprehend government's visions and objectives about security. The dissemination of information about security threats and after attacks is a sure way of recovery from disunity and ensures the survival of national identity by creating cross-cultural understanding that helps in building national consciousness and security approaches. This distinctiveness can be used in appreciating Nigeria's shared or common history as the foundation of national identity. Their economic relations in different epochs express the necessity of complementary role of the people which by extension emphasizes unity long before the amalgamation of the Southern and Northern Protectorates to form Nigeria by the British in 1914. Novels on dramatic creations have stage 
The Humanities and National Identity, Security and Social Stability in Nigeria: History and Theatre as the way Forward- Ama Doki Gowon, PhD, \& Elijah Terdoo Ikpanor

managed plays with national characteristics. These have played positive roles in promoting the process of national identity in Nigeria.

Thus, by de-emphasizing ethnic consciousness, the humanities also provide the understanding of the radical ideologies, crosscultural exchanges with other ethnic groups; understand opportunities which traditionally build reservoirs of mutual coexistence and social stability. In Nigeria particularly, the humanities offer a comprehensive understanding of religious affiliations and factors that influence the evolution of sects and extremism. The current terrorism threats of Boko-Haram insurgence that brought insecurity to Nigeria can be seen in a religious extremist or sectionist point of view which the humanities have offered a rich understanding. By this understanding, the humanities have expanded the capacities of officers in the national security environment to evaluate the country in line with the current and anticipated national policies and initiatives of building peace especially the call for amnesty for members of the Boko Haram just like the militants in the Niger Delta.

\section{Adopting History and Theatre for the Way Forward}

Like other disciplines in the humanities, history and theatre contribute enormously to the security, national identity and social stability of societies and can foster such scenario in Nigeria. History particularly as observed by Robert (1972:6) is the memory of human group experience. If it is forgotten or ignored, we cease in that measure to be human. Thus, without history, we have no knowledge of who we are or how we came to be, like victim of collective amnesia grouping in the dark for our identity. It is the events recorded in history that generate all emotions, the values, the ideals that make life meaningful, that give men something to live for, struggled over and die for. 
Historical events have created all the basic human groupings, countries, religions, classes and all the loyalties that are attached to these. In Nigeria, historical consciousness brings both unique and diverse experiences in focus on the national identity. It should be noted that through history, we have understood how groups interacted with each other before the amalgamation of the northern and southern protectorates to form Nigeria. These inter-group relations were peacefully coordinated as in the case of the Etsu of Nupe who sought the advice of Balogun of Abeokuta and the Sultan of Sokoto that mediated in the Yoruba civil wars (Asiwaju, 1984). Lessons from these interactions prove that Nigerian people can peacefully co-exist and maintain harmonious relationship against the backdrop that what characterized Nigerian people was conflict or wars. Thus, it was also history that made us common people. The formation and long existence of Nigeria through the aggregation of different groups to form an entity and maintaining the collusion have convincingly brought our national identity into spotlight. The knowledge of history and theatre makes Nigerians understand their culture and can help leaders navigate the increasing number of multi-cultural issues that need multi-cultural solutions in the security situation of Nigeria.

Nigeria progresses on the foundation of past events and historical enterprise adopts the study of the past which is constantly impinging on the present. It is with this knowledge that Nigeria has safeguarded and preserved its independence even with the turbulent periods of civil war and military dictatorships. The identity Nigeria fosters is also manifested through cultural exhibition through theatre. As observed by Doki (2004:70), the instrument of theatre through play 
The Humanities and National Identity, Security and Social Stability in Nigeria: History and Theatre as the way Forward- Ama Doki Gowon, PhD, \& Elijah Terdoo Ikpanor

employs dramatic action that seeks to communicate with an identifiable audience.

Both drama and literally works have made significant reflections on Nigerian society and have also influenced national identity and cohesion among the people of Nigeria. Theatre which focuses on interpretation and ideals of the society uses different forms like music, dance, song, poetry, narration and drama, etc to reach out to the audience. It is imperative to note that theatre has brought impact on group identity in pre-colonial African societies through the aforementioned forms. Kerr (1986:10) elaborated on this when he opined that African theatre is highly relevant to society... for example, oral narrative, initiation ceremonies and comic masquerades are explicitly didactic, being instrumental in the socialization of the young by providing role models.

Extrapolating from the above, theatrical appeal to national identity and social stability is seeing in the present home video films, dance and songs. The services of theatre through both on radio, television and stage can employ stories on the significance of national identity and also project the importance of security for the survival of Nigeria through social stability. Here, we can see theatre engineering interethnic interactions, struggle for national identity and provision of basic ethos of security. The relevance of theatre in social awareness and mobilization for change cannot be underestimated and should be harnessed for social identity and mobilization for the security of Nigeria.

\section{Conclusion}

The humanity disciplines afford the people with the opportunity to know about the positive aspects of their socioeconomic and political aspects, factors promoting Unity and 
Solidarity among the numerous ethnic groups making up Nigeria. They provide the basis for need to reforms or changes as well as catering for its survival by eliminating barriers between groups and classes as a result of birth, occupation, language, race and religion and even between generation and ethnic groups. Various themes in the humanities concerning safety and national security are designed to promote national and international security. They provide international understanding by emphasizing the essential oneness of the people of Nigeria to realize the growing interdependence of nation and people. By this the humanities develop a frame work for conflict prevention management and ensuring national security in Nigeria. Knowledge of history, foreign languages and cultures can help Nigeria more successfully navigate the increasing number of multinational issues that need multinational solutions. To this extent the humanities can play a critical or essential role in ensuring inter - ethnic cohesion providing national security through social stability.

\section{Works Cited}

Adam Roberts (2010). Past, Present and Future, The Public Value of Humanities and Social Science: Introduction. London, The British Academy, Charton House Terrace.

Aiswaju, A.I. (1984) "History and National Awareness in Nigeria" In Erim O.E. and Uya, O.E. (eds) Perspectives and Methods of Studying African History. Enugu: Fourth Dimension Publishing Company.

Aliyu, A.Y. (1975). "Intergroup Conflict and Integration in Nigeria in Akeredolu-Ale, E.O. (ed). General Proceedings of the Conference on Social Research and National Development in Nigeria; NISER, Ibadan, Sept. 27-Oct. 4, vol. II. 
Arisi Regina, (2011) "Social Studies Education as a Panacea for National Security in Nigeria" in African Review: An International Multi Disciplinary Journal, Ethiopia Vol. 5 (2), Serial No. 19, April, 2011. Indexed African Journals. Online: www.ajol.info (Pp. 254-262)

Doki, G.A. (2004) "Intricacies of Managing Information for a Successful Democratic Culture in Nigeria: A Theatre Proposal" In FASS: Journal of Faculty of Arts, seminar series, Makurdi, A Publication of the Faculty of Arts, Benue State University, Makurdi.

Ibrahim, J., (2000) "The Transformation of Ethno-Regional Identities in Nigeria" in Identity Transformation and Identity Politics under Structural Adjustment in Nigeria, Uppsala, The Nordic African Institute.

Ibrahim, J., (2003) "Ethno-Religious Limits to the Construction of Federalism in Africa: Yugoslavia and Nigeria Compared", in Aaron Gana and Samuel Egwu (ed.) Federalism in Africa, Volume 1: Framing the National Question, Trenton, Africa World Press.

Ikime, O. (2002) "The Nigerian Civil War and the National Question" in Osaghae, E. Onwundiwe, E. and Sebeu, R. (ed.) The Nigerian Civil War and its Aftermath, Ibadan, John Archers (Publishers) for Programme on Ethnic and Federal Studies.

Imobighe T.A. et al (1992). "Doctrines for and threats to internal security" in Ekoko, A.E and Vogt, M.A (eds) Nigerian Defence Policy; Issues and Problems. Lagos, Malthouse press Ltd. 
Kerr, David (1986). "An Approach to pre-colonial African Theatre' In African Theatre Review. Ibadan: Heinemann Education books.

Khan A. R., (1987). "The security of small state; A framework of analysis." In Hafiz, M.A Khan, A.R etal (eds), Security of small states, Dhaka, UPL.

Kuna, M., (1999) "The Sokoto Caliphate, Colonialism and the Formation of Identities: The Construction of Northern Nigeria", Annals of the Social Science Council of Nigeria, 10

Mustapha, R., (1997) "Ethnicity and Democratization Process in Nigeria" in Jibrin Ibrahim (ed.), Expanding Democratic Space in Nigeria, Dakar, CODESRIA

Ogunbanwo, S. (1997). "Electoral Violence and National Security in Nigeria' Africa peace Review, Vol. 1, April.

Omu Fred, (1996) "Ethnicity and Federalism" in Eliagwu, I. J. and Uzogwe G. N. (ed.) Foundation of Nigeria/Federalism 1960 - 1990, Jos, Midland Press

Renz Loren, Steven Lawrence, and James Allen Smith (2004). Foundation Funding for the Humanities: An Overview of Current and Historical Trends. New York, The American Academy of Arts and Sciences.

Robert, U.D. (1972) Studying History, How and Why, New Jersey: Eaglewood Cliffs. 